\title{
INTERLEUKIN AS BIOMARKER OF RECURRENT APHTHOUS STOMATITIS (RAS): A SYSTEMATIC LITERATURE REVIEW
}

\author{
INDAH DAMAYANTI ${ }^{1}$, NANAN NUR'AENY ${ }^{2}$, INDAH SUASANI WAHYUNI ${ }^{2}$
}

1Undergraduate Program of Dentistry, Faculty of Dentistry, Universitas Padjadjaran, Jl. Raya Bandung-Sumedang km 21, Jatinangor, Sumedang, West Java, 45363, 2Department of Oral Medicine, Faculty of Dentistry, Universitas Padjadjaran, Jl. Sekeloa Selatan no 1,

Bandung, West Java, Indonesia 40132

Email: indah.wahyuni@fkg.unpad.ac.id

Received: 05 Aug 2021, Revised and Accepted: 13 Oct 2021

\begin{abstract}
This review aimed to describe the interleukins and interleukin gene polymorphisms related to and recommended as a RAS biomarker. Articles were searched through PubMed, ScienceDirect, and Cochrane Library databases, using the keywords of "Interleukin" AND "Recurrent Aphthous Stomatitis". The Risk of Bias Assessment tool for Non-randomized Studies (RoBANS) was used, and the writing of this review refers to the Preferred Reporting Items for Systematic Review and Meta-analysis (PRISMA) guidelines. A total of 8 articles met the criteria and showed a low risk of bias assessment. The level of IL-2, IL-6, IL-8, and IL-18 in the acute clinical phase of RAS were higher than in the recovery phase, but IL-10 levels showed decreased. IL-2, IL-6, IL-10 gene polymorphisms were found to be more frequent in RAS patients compared to controls, while IL-12 gene polymorphisms were found to be less associated with RAS pathogenesis. Interleukins at the proteomic level that recommended as a proinflammatory biomarker are IL-2, IL-6, IL-8, IL-12, and IL-18, while an anti-inflammatory is IL-10. Only IL-2 can be recommended as a biomarker at the genomic level, as other interleukins still require more investigation.
\end{abstract}

Keywords: Interleukin, Recurrent aphthous stomatitis, Biomarker, Gene polymorphism

(C) 2021 The Authors. Published by Innovare Academic Sciences Pvt Ltd. This is an open access article under the CC BYlicense (https://creativecommons.org/licenses/by/4.0/) DOI: https://dx.doi.org/10.22159/ijap.2021.v13s4.43813 Journal homepage: https://innovareacademics.in/journals/index.php/ijap

\section{INTRODUCTION}

Interleukin (IL) plays a role in the immune system, including oral cavity immunity. These important roles include: the activation, differentiation, proliferation and maturation process, also migration and adhesion of immune cells [1]. Interleukins are both proinflammatory and anti-inflammatory, so that the main function of interleukins is to modulate the growth, differentiation, and activation of immune cells during the inflammatory response $[1,2]$. Interleukin produced by lymphocytes and other cells such as macrophages, eosinophils, mast cells, endothelial cells, and dendritic cells [2]. The synthesis of IL protein begins by copying the deoxyribonucleic acid (DNA) sequence, which will then be expressed in the nucleus. Furthermore, the transcription process starts with separating hydrogen bonds between the nitrogen bases in DNA by the enzyme helicase, resulting in the genetic code and copied into the ribonucleic acid (RNA) molecules $[3,4]$. The genetic code is translated in the ribosomes into polypeptides with specific amino acid sequences, then according to the central dogma can increase or suppress in IL protein expression. Interleukin expression is influenced by changes at the genomic level called gene polymorphisms [1, 3].

Interleukin is a small protein secreted by cells and has a specific effect on the interaction and communication between leukocytes during inflammation [5]. Systematically increased Th1 cytokines and local transcription of Th1 genes production have been reported in patients with Recurrent Aphthous Stomatitis (RAS), which is an inflammatory disease of the oral mucosa [6]. IL-2 and IFN- $\gamma$ are two cytokines secreted by Th1 cells, which are considered to be proinflammatory cytokines. Increased levels of both cytokines have also been reported in a group of patients with RAS [7].

RAS is one of the oral diseases often found in Indonesian society, and is also known as "sore mouth" [8]. The etiology of RAS is still not known with certainty [8-10]. However, one of the predisposing factors is genetic, because it is associated with the discovery of the Single Nucleotide Polymorphism (SNP), and the history of RAS is often found in several members of the same family [11]. Genes with polymorphisms have allele or genotype variations at one or more loci of these genes, with a prevalence of at least $1 \%$ in a given population [11, 12]. Gene polymorphisms encoding interleukins associated with RAS in certain populations, can be detected early so that they can help determine individual risk factors in that population [12].

Another known risk factor for RAS is impaired local immunologic response $[7,9,13]$. Impaired local immune response is mediated by oral mucosal epithelial cells. This causes the accumulation of $\mathrm{T}$ lymphocytes and increased production of pro-inflammatory cytokines, thus triggering damage to oral mucosal tissue, in the form of ulcers and causing stomatitis [14]. Cytokines found to be associated with RAS include IL-1 $\beta$, INF- $\gamma$, and TNF- $\alpha$ [11]. Gene polymorphisms of IL-10 in European and American populations [15], and also IL-1 $\beta$ in European, American [15], and Brazilian populations [16], have also been reported to be associated with the pathogenesis of RAS. Based on these, interleukins at the proteomic and genomic levels related to RAS are interesting and important to explore.

This recent review aimed to explore interleukins at the proteomic and genomic levels in the RAS patient population, without limiting the interleukin types. So far, this theme has not been found published in scientific journals in the last $10 \mathrm{y}$. Thus, it is hoped that this review article can become a complement and provide the latest scientific information updates regarding the characteristics and role of IL as a RAS biomarker. Another advantage is that the results of this review can be used as the basis for further research material related to the risk factors, diagnosis, and novel treatment of RAS, as well as for the application in the developing of new drugs or monitor the therapeutic effects.

\section{Method}

This systematic review follows the Preferred Reporting Items for Systematic Review and Meta-analysis (PRISMA) guidelines, and the research questions were structured using PICO (population, intervention, comparison, and outcome) framework. The population was patients with the diagnosis of RAS; the intervention was the measurement of interleukin levels and examination of interleukin gene polymorphisms; the comparison was healthy control/non-RAS patient, or healing phase when compared with the acute phase of the same subject; and the outcomes were the effects/results of the intervention. The article to be reviewed was searched using the keywords of "Interleukin" AND "Recurrent Aphthous Stomatitis" ("interleukin"[All Fields] OR "interleukins"[All Fields] OR "interleukins"[MeSH Terms] OR "interleukins"[All Fields] OR "interleukin"[All Fields]) AND 
("recurrence"[All $\quad$ Fields] $\quad$ OR $\quad$ "recurrence"[MeSH $\quad$ Terms $] \quad$ OR "recurrence"[All Fields] OR "recurrences"[All Fields] OR "recurrences"[All Fields] OR "recurrency"[All Fields] OR "recurrent"[All Fields] OR "recurrently"[All Fields] OR "recurrent"[All Fields]) AND ("stomatitis, aphthous"[MeSH Terms] OR ("stomatitis"[All Fields] AND "aphthous"[All Fields]) OR "aphthous stomatitis"[All Fields] OR ("aphthous"[All Fields] AND "stomatitis"[All Fields])). The digital databases used were PubMed, Science Direct, and Cochrane Library. Additional articles searched were also carried out manually by viewing the list of the article references and would be used if they were relevant to the research question.

The inclusion criteria were articles published in the last ten years (2010-2020), in English, available full paper, and specifically address the topic of interleukins in patients with RAS. The exclusion criteria were articles with case report or meta-analysis design study. The identification and screening process was carried out by ID and NN, while the risk assessment procedure was carried out by ID and ISW independently. There was no difference in the results of the risk assessment of bias between the two raters.

The data extracted from the reviewed articles consists of: the type of IL or gene polymorphism in RAS patients, the total population of RAS and controls, the country where the research is carried out or the origin of the population, sample materials, research methods, results, and conclusions. The reviewed articles were assessed for eligibility using the Risk of Bias Assessment tool for Non-randomized Studies (RoBANS), so that articles with low risk of bias and good quality were obtained. RoBANS consisted of six domains: selection of participants, confounding variables, intervention (exposure) measurement, blinding of outcome assessment, incomplete outcome data, and selective reporting. Each assessment item is a question that has an assessment point $=1$ for the answer "YES" or "Available", while the scoring point $=0$ for the answer "NO" or not available. The total score is the sum of the points from the six questions, so the total points range from 0-6. The assessment criterias were: the risk of bias is high or the quality of the article is low if the total points are between 0 and 2 , and the risk of bias is low or the quality of the article is high if the total points are between 3 and 6 . All selected articles were then reviewed based on the qualitative analysis or thematic analysis according to the research objectives. The thematic analysis was carried out by identifying and grouping data from articles based on the similarity of specific themes or characteristics or based on the results or conclusions of each article [17].

\section{RESULTS}

Articles identified using keywords, resulted in 93 articles from the PubMed database, 406 articles from the Science Direct, and two articles from the Cochrane Library. The screening process using database filters and inclusion criteria obtained nine articles from the PubMed database, four articles from the Science Direct database, and two articles from the Cochrane Library database so that a total of 15 articles were obtained. Furthermore, nine articles had been excluded because they were not in accordance with the research objectives. Two additional articles were then manually identified from the bibliography of the six previously selected articles. A total of eight articles were obtained at the end of the screening stage, which were then assessed for their eligibility using the risk of bias tools and could be reviewed qualitatively. The following in fig. 1 is a flowchart of searching and selecting articles in this research.

Table 1 shows the characteristics of the researched studies based on the examination of interleukin levels. Two articles showed that the research conducted in India $[18,21]$, two articles in Turkey [19, 25], three articles in Iran [22-24], and one article in China [20]. The number of research subjects in each article consists of 25 to 184 RAS patients, or 551 patients with RAS diagnoses in total. The control subjects consist of 20 to 150 subjects per article, resulting in a total number of 706 control subjects. This review was conducted on 7 observational study articles and one article with the clinical study design. Four articles studied the interleukin levels in RAS and four articles examined the interleukin gene polymorphisms in RAS.

Table 2 shows the characteristics of the reviewed studies based on the examination of gene polymorphisms through blood samples. The RAS associated gene polymorphisms studies consisted of specific alleles and genotypes of IL-2 [22], IL-12 [23], IL-10 [24], and IL-6 [25], using gene sequencing analysis of polymerase chain reaction (PCR) [22-25]. Meanwhile, table 3 is the results from the risk of bias assessment to determine the quality of the selected articles.

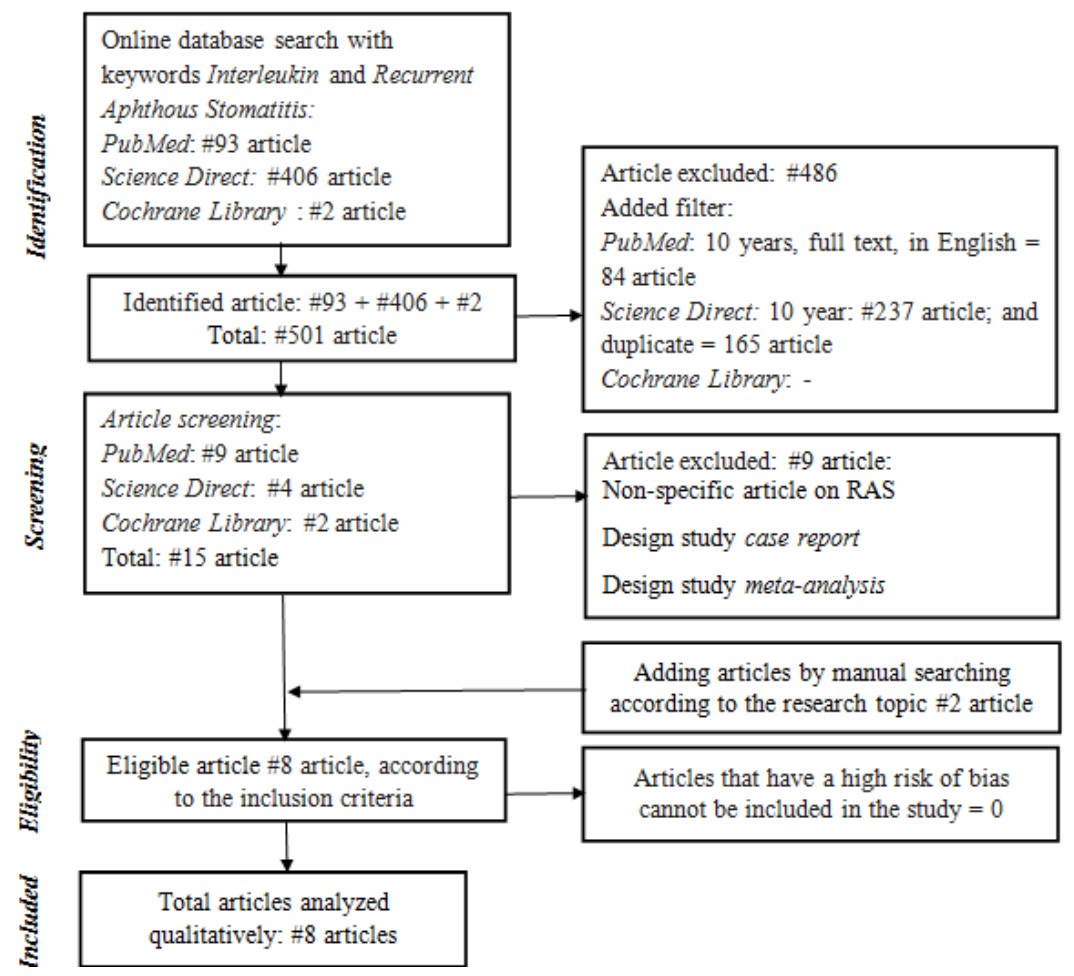

Fig. 1: Flowchart of article search and selection process 
Table 1: Characteristics of the reviewed studies based on proteomic level examination

\begin{tabular}{|c|c|c|c|c|c|c|c|c|c|}
\hline No & Researcher & Aim & Population & Country & Interleukin & Sample & Method & Result & Conclusion \\
\hline 1 & $\begin{array}{l}\text { Kalpana et } \\
\text { al., } 2014 \\
{[18]}\end{array}$ & $\begin{array}{l}\text { To measure } \\
\text { and } \\
\text { compare } \\
\text { the salivary } \\
\text { IL-2 levels } \\
\text { of RAS } \\
\text { patients } \\
\text { with } \\
\text { healthy } \\
\text { control, and } \\
\text { the } \\
\text { variations } \\
\text { in age and } \\
\text { sex. }\end{array}$ & $\begin{array}{l}60 \text { patients, } \\
\text { age of } 16-60: \\
-\quad 30 \text { RAS } \\
\text { patients ( } 17 \\
\text { females and } \\
13 \text { males) } \\
-\quad 30 \\
\text { healthy } \\
\text { controls (18 } \\
\text { females and } \\
12 \text { males) }\end{array}$ & India & IL-2 & Saliva & $\begin{array}{l}\text { Determination } \\
\text { of the IL-2 } \\
\text { saliva }(\mathrm{pg} / \mathrm{ml}) \\
\text { using the } \\
\text { enzyme-linked } \\
\text { immunosorbent } \\
\text { assay (ELISA) } \\
\text { method. }\end{array}$ & $\begin{array}{l}\text { Salivary IL-2 levels } \\
\text { were higher in: } \\
\text { 1. RAS patients } \\
\text { than healthy } \\
\text { controls. } \\
\text { 2. Patients in the } \\
\text { age group of } 16-30 \\
\text { y compared to the } \\
\text { other age groups. } \\
\text { 3. Female than } \\
\text { male patients. }\end{array}$ & $\begin{array}{l}\text { IL-2 was a } \\
\text { pro- } \\
\text { inflammatory } \\
\text { interleukin in } \\
\text { RAS. }\end{array}$ \\
\hline 2 & $\begin{array}{l}\text { Avci et al., } \\
2014 \text { [19] }\end{array}$ & $\begin{array}{l}\text { To measure } \\
\text { and } \\
\text { compare } \\
\text { the levels } \\
\text { of IL-2, IL- } \\
10 \text {, and IL- } \\
12 \text { of the } \\
\text { RAS } \\
\text { patients } \\
\text { and healthy } \\
\text { controls. }\end{array}$ & $\begin{array}{l}-25 \text { RAS } \\
\text { patients } \\
-25 \text { healthy } \\
\text { controls ( } 26 \\
\text { females and } \\
24 \text { males at } \\
\text { the age of } \\
19-40 \text { y) }\end{array}$ & $\begin{array}{l}\text { Gazi, } \\
\text { Turki }\end{array}$ & $\begin{array}{l}\text { IL-2, IL-10, } \\
\text { IL-12 }\end{array}$ & Blood & $\begin{array}{l}\text { Determination } \\
\text { of the levels of } \\
\text { IL-2, IL-10, and } \\
\text { IL-12 from } \\
\text { blood samples } \\
\text { using the ELISA } \\
\text { method. }\end{array}$ & $\begin{array}{l}\text { 1. The levels of IL-2 } \\
\text { and IL-12 in the } \\
\text { blood of RAS } \\
\text { patients were higher } \\
\text { than in healthy } \\
\text { controls. } \\
\text { 2. The levels of IL-10 } \\
\text { in the blood of RAS } \\
\text { patients were lower } \\
\text { than in healthy } \\
\text { controls. }\end{array}$ & $\begin{array}{l}\text { IL-2 and IL- } \\
12 \text { were pro- } \\
\text { inflammatory } \\
\text { interleukins, } \\
\text { while IL-10 is } \\
\text { an anti- } \\
\text { inflammatory } \\
\text { interleukin in } \\
\text { RAS. }\end{array}$ \\
\hline 3 & $\begin{array}{l}\text { Lu et al., } \\
2020[20]\end{array}$ & $\begin{array}{l}\text { To } \\
\text { measure, } \\
\text { compare } \\
\text { and } \\
\text { determine } \\
\text { the } \\
\text { relations of } \\
\text { plasma IL-6 } \\
\text { and IL-18 } \\
\text { levels with } \\
\text { RAS. }\end{array}$ & $\begin{array}{l}\text { - } \quad 60 \text { RAS } \\
\text { patients } \\
-\quad 60 \\
\text { healthy } \\
\text { controls ( } 30 \\
\text { males and } \\
30 \text { females } \\
\text { at the age of } \\
25-44 \mathrm{y} \text { ) }\end{array}$ & $\begin{array}{l}\text { Shanghai } \\
\text { Xuhui, } \\
\text { China }\end{array}$ & $\begin{array}{l}\text { IL- } 6 \text { and IL- } \\
18\end{array}$ & Plasma & $\begin{array}{l}\text { Determination } \\
\text { of the plasma } \\
\text { IL- } 6 \text { and IL-18 } \\
\text { levels (pg/ml), } \\
\text { using the ELISA } \\
\text { method. }\end{array}$ & $\begin{array}{l}\text { 1. The levels of IL-6 } \\
\text { and IL-18 in plasma } \\
\text { of RAS patients were } \\
\text { significantly higher } \\
\text { and showed a close } \\
\text { relation compared to } \\
\text { healthy controls. } \\
2 \text {. The levels of IL-6 } \\
\text { and IL-18 in the } \\
\text { plasma of RAS } \\
\text { patients were lower } \\
\text { after recovery. }\end{array}$ & $\begin{array}{l}\text { IL- } 6 \text { and IL- } \\
18 \text { were pro- } \\
\text { inflammatory } \\
\text { interleukins } \\
\text { in RAS. }\end{array}$ \\
\hline 4 & $\begin{array}{l}\text { Gupta et al., } \\
2014 \text { [21] }\end{array}$ & $\begin{array}{l}\text { To } \\
\text { measure, } \\
\text { compare } \\
\text { and } \\
\text { evaluate } \\
\text { the effect of } \\
\text { levamisole } \\
\text { therapy on } \\
\text { IL-8 serum } \\
\text { levels in } \\
\text { RAS } \\
\text { patients } \\
\text { compared } \\
\text { to healthy } \\
\text { controls. }\end{array}$ & $\begin{array}{l}\text { - } 20 \text { healthy } \\
\text { controls } \\
\text { - } 30 \text { RAS } \\
\text { patients } \\
\text { treated with } \\
\text { levamisole } \\
\text { for } 3 \text { mo. }\end{array}$ & India & IL-8 & Serum & $\begin{array}{l}\text { Determination } \\
\text { of the levels of } \\
\text { IL- } 8 \text { in serum } \\
\text { using the } \\
\text { enzyme } \\
\text { immunoassay } \\
\text { IL-8 } \\
\text { immunotech } \\
\text { method (IM } \\
\text { 2237). }\end{array}$ & $\begin{array}{l}\text { 1. IL-8 serum levels } \\
\text { in RAS patients } \\
\text { before levamisole } \\
\text { therapy were } \\
\text { significantly higher } \\
\text { than in healthy } \\
\text { controls. }(\mathrm{t}=6.53 \text {, } \\
\mathrm{P} \leq 0.001) \text {. } \\
2 . \text { IL-8 serum levels } \\
\text { in RAS patients } \\
\text { were significantly } \\
\text { reduced by } 72 \% \\
\text { after levamisole } \\
\text { therapy compared } \\
\text { to before therapy }(\mathrm{t} \\
=5.54, \mathrm{P} \leq 0.001) .\end{array}$ & $\begin{array}{l}\text { IL-8 was a } \\
\text { pro- } \\
\text { inflammatory } \\
\text { interleukin in } \\
\text { RAS and can } \\
\text { be inhibited } \\
\text { by } \\
\text { levamisole. }\end{array}$ \\
\hline
\end{tabular}

Table 2: Characteristics of the reviewed studies based on genomic level examination

\begin{tabular}{|c|c|c|c|c|c|c|c|c|c|}
\hline $\begin{array}{l}\mathbf{N} \\
\mathbf{o}\end{array}$ & $\begin{array}{l}\text { Researche } \\
\mathbf{r}\end{array}$ & Aim & Population & $\begin{array}{l}\text { Countr } \\
y\end{array}$ & $\begin{array}{l}\text { Interle } \\
\text { ukin }\end{array}$ & Sample & Method & Result & Conclusion \\
\hline 1 & $\begin{array}{l}\text { Najafi S et } \\
\text { al., } 2017 \\
{[22]}\end{array}$ & $\begin{array}{l}\text { To investigate } \\
\text { the frequency } \\
\text { of IL-2 (G-330 } \\
\text { T), (G+166 T) } \\
\text { alleles and } \\
\text { genotypes in } \\
\text { RAS patients } \\
\text { compared to } \\
\text { healthy } \\
\text { controls. }\end{array}$ & $\begin{array}{l}\text { - } 64 \text { Iranians } \\
\text { with RAS (24 } \\
\text { males and } 40 \\
\text { females) } \\
\text { - } 141 \\
\text { healthy } \\
\text { controls (101 } \\
\text { males and } 40 \\
\text { females) }\end{array}$ & Iran & IL-2 & $\begin{array}{l}\text { Blood: IL-2 } \\
\text { alleles and } \\
\text { genotypes }\end{array}$ & $\begin{array}{l}\text { Phenol- } \\
\text { chloroform } \\
\text { method for } \\
\text { isolation of } \\
\text { DNA: Gene } \\
\text { Sequencing } \\
\text { of IL-2 using } \\
\text { polymerase } \\
\text { chain } \\
\text { reaction/seq } \\
\text { uence- } \\
\text { specific }\end{array}$ & $\begin{array}{l}\text { 1. IL-2 }(+166 G) \\
\text { alleles were } \\
\text { lower in RAS } \\
\text { patients than in } \\
\text { controls. } \\
\text { 2. IL-2 }(+166 T) \\
\text { alleles were } \\
\text { higher in RAS } \\
\text { patients than in } \\
\text { controls. } \\
\text { 3. IL-2 GT } \\
\text { genotypes were }\end{array}$ & $\begin{array}{l}\text { Specific Single } \\
\text { Nucleotide } \\
\text { Polymorphism } \\
\text { (SNP) of the } \\
\text { IL-2 gene was } \\
\text { associated } \\
\text { with } \\
\text { individual } \\
\text { predisposition } \\
\text { to RAS in } \\
\text { Iranians } \\
\text { ethnicity. }\end{array}$ \\
\hline
\end{tabular}




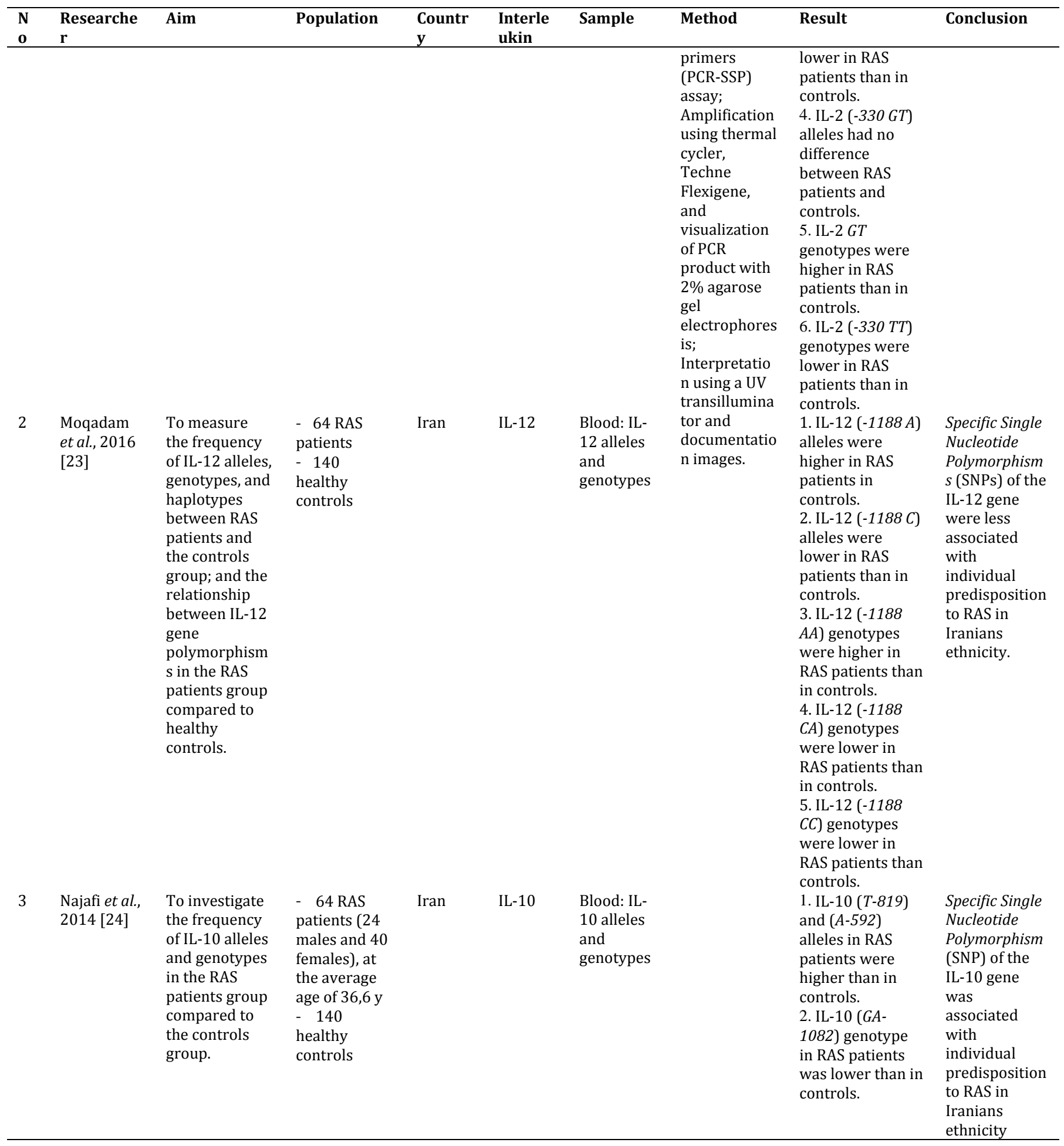

Table 2: Characteristics of the reviewed studies based on genomic level examination (continued)

\begin{tabular}{|c|c|c|c|c|c|c|c|c|c|}
\hline No & Researcher & Aim & Population & Country & Interleukin & Sample & Method & Result & Conclusion \\
\hline 4 & $\begin{array}{l}\text { Karakus et } \\
\text { al., } 2014 \\
{[25]}\end{array}$ & $\begin{array}{l}\text { To investigate } \\
\text { the } \\
\text { polymorphisms } \\
\text { relation of IL-6 } \\
\text { gene in RAS } \\
\text { patients } \\
\text { compared to } \\
\text { healthy } \\
\text { controls in the } \\
\text { Turkish }\end{array}$ & $\begin{array}{l}\text { - } 184 \text { RAS } \\
\text { patients ( } 66 \\
\text { males and } \\
118 \text { females), } \\
-\quad 150 \\
\text { healthy } \\
\text { controls ( } 62 \\
\text { males and } 88 \\
\text { females) }\end{array}$ & Turkey & IL-6 & $\begin{array}{l}\text { Blood: IL- } \\
6 \\
\text { genotypes }\end{array}$ & $\begin{array}{l}\text { Genomic DNA } \\
\text { isolation } \\
\text { using } \\
\text { commercial } \\
\text { DNA isolation } \\
\text { kits; IL-6 } \\
\text { gene was } \\
\text { analyzed } \\
\text { using the PCR } \\
\text { based on the }\end{array}$ & $\begin{array}{l}1 .(-572 G \geq C) \\
\text { genotypes, } \\
G G+G C \\
\text { genotypes } \\
\text { and } G(- \\
572 G \geq C) \\
\text { alleles, }(- \\
174 G \geq C) \\
\text { genotypes, } \\
\text { and } G G\end{array}$ & $\begin{array}{l}\text { IL-6 gene } \\
\text { polymorphisms } \\
\text { were found in } \\
\text { RAS patients } \\
\text { and associated } \\
\text { with individual } \\
\text { predisposition } \\
\text { to RAS in the } \\
\text { Turkish } \\
\text { population. }\end{array}$ \\
\hline
\end{tabular}




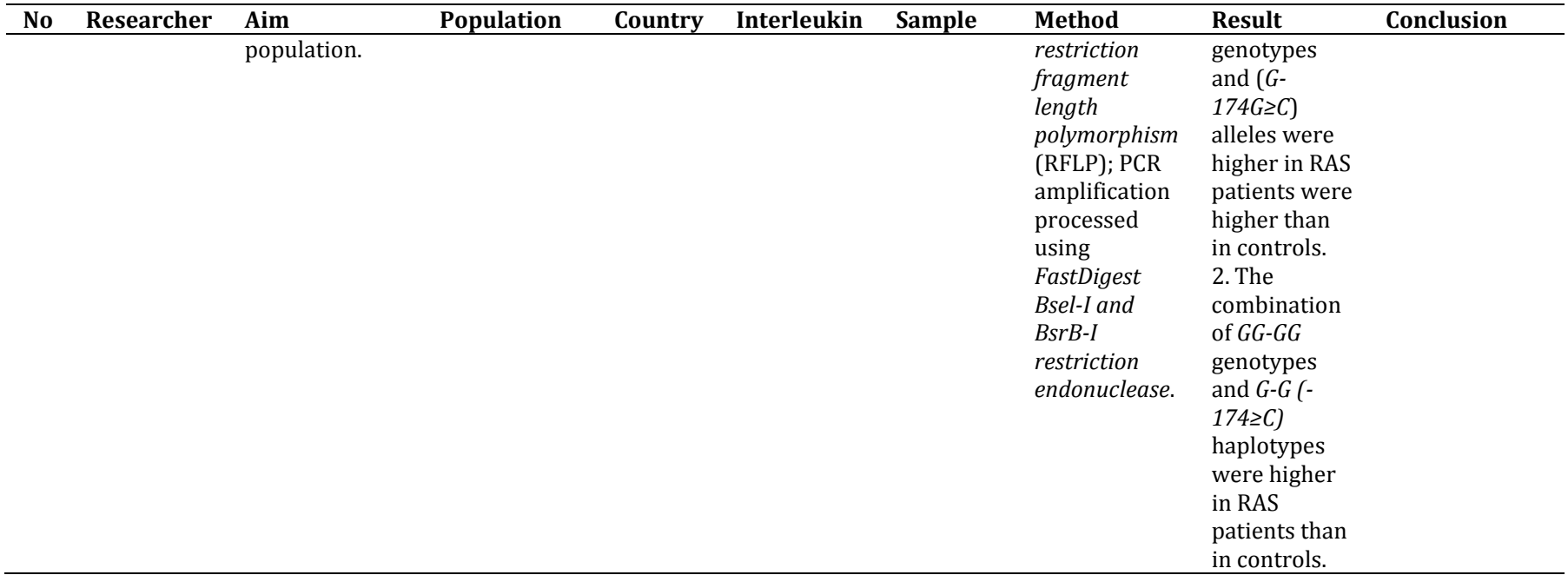

Table 3: Risk of bias assessment (RoB)

\begin{tabular}{|c|c|c|c|c|c|c|c|c|c|c|}
\hline \multirow[t]{2}{*}{ No } & \multirow[t]{2}{*}{ Researcher } & \multicolumn{6}{|c|}{ Risk assessment of Bias/Item } & \multirow{2}{*}{$\begin{array}{l}\text { Total } \\
\text { point }\end{array}$} & \multirow{2}{*}{$\begin{array}{l}\text { Assessment } \\
\text { of } R o B\end{array}$} & \multirow[t]{2}{*}{ Conclusion } \\
\hline & & Item 1 & Item 2 & Item 3 & Item 4 & Item 5 & Item 6 & & & \\
\hline 1 & Kalpana et al., 2014 [18] & 1 & 1 & 1 & 0 & 1 & 1 & 5 & Low & High quality \\
\hline 2 & Avci et al., 2014 [19] & 1 & 1 & 1 & 0 & 1 & 1 & 5 & Low & High quality \\
\hline 3 & Lu et al., 2020 [20] & 1 & 1 & 1 & 0 & 1 & 1 & 5 & Low & High quality \\
\hline 4 & Gupta et al., 2014 [21] & 1 & 1 & 1 & 0 & 1 & 1 & 5 & Low & High quality \\
\hline 5 & Najafi S et al., 2017 [22] & 1 & 1 & 1 & 0 & 1 & 1 & 5 & Low & High quality \\
\hline 6 & Moqadam et al., 2016 [23] & 0 & 1 & 1 & 0 & 1 & 0 & 3 & Low & High quality \\
\hline 7 & Najafi et al., 2014 [24] & 1 & 1 & 1 & 0 & 1 & 1 & 5 & Low & High quality \\
\hline 8 & Karakus et al., 2014 [25] & 1 & 1 & 1 & 0 & 1 & 1 & 5 & Low & High quality \\
\hline \multicolumn{2}{|c|}{ Domain Assessment (\%) } & 87,5 & 100 & 100 & 0 & 100 & 87,5 & - & - & - \\
\hline
\end{tabular}

Ex: Item 1 = Selection of participants; Item 2 = Confounding variables; 3 = Intervention (exposure) measurement; Item 4 = Blinding of outcome assessment; Item $5=$ Incomplete outcome data; Item $6=$ Selective outcome reporting; $1=$ Yes/available; $0=$ No/not available; Total point $0-2=$ High risk of bias; Total point 3-6 = Low risk of bias.

The results of the risk assessment of bias for the eight articles mentioned above show that all articles had a low risk of bias assessment and had good quality. Domain selection of participants (item 1) and selective outcome reporting (item 6) had a percentage score of $87.5 \%$, and this score was considered good because only one of the eight articles in the two domains did not fulfil the criteria. The Confounding variables domain (item 2), intervention (exposure) measurement domain (item 3), and incomplete outcome data domain (item 5) had a percentage score of $100 \%$, and this score was very good because all articles met the expected criteria. All research subjects had followed the research procedure flow and completed it. The worst percentage score was in the domain of blinding of outcome assessment (item 4), which is $0 \%$ because the entire article did not mention the blinding method in the research procedure. It may be because 7 out of 8 articles were observational studies based on objective assessments, both interleukin levels, and gene polymorphisms, not clinical trial studies that assess subjectively, so they were often not blinded.

\section{DISCUSSION}

Tables 1 and 2 show that the research was conducted on populations in Iran, Turkey, India, and China which are part of the West, South, and East Asian continent. Previously published articles show that research on RAS-related interleukins has been carried out in European (United Kingdom, Italy, and Finland) and American populations including Brazillian [15-17], so our review is a complement to the existing scientific information.

Studies on interleukins as biomarkers associated with RAS consist of studies at the proteomic [18-21] and genomic levels [22-25]. A total of three articles researched IL-2 [18, 19, 22]; two articles researched IL-12 [19, 23]; two articles researched IL-10 [19, 24], two articles researched IL-6 [20, 25], one article researched IL-8 [21], and one article researched IL-18 [20]. Overall, this review results showed that interleukins and IL gene polymorphisms play a role in the pathogenesis of RAS and showed a positive correlation.

There were various sample materials used. Saliva [18], is the most accessible and non-invasive sampling method. Saliva generally reflects blood peptide concentrations and plays a crucial role in oral health to maintain the integrity of the oral mucous membranes through liquefaction and repair of soft tissues [26], so that IL products can be detected in saliva. Interleukins are more systematically distributed in the blood circulation [19-25], but blood sampling is a more invasive procedure than saliva sampling. Blood samples are also used for gene polymorphism examination using the polymerase chain reaction (PCR) method [22-25]. This PCR method can multiply specific DNA up to millions of copies in vitro, and can be analyzed more clearly with more specific and accurate results, particularly in detecting the specific alleles and genotypes encoding the IL productions [27].

IL-2 levels had been examined using saliva [18] and blood [19, 22] samples. The examination results obtained that salivary and blod IL2 levels in RAS patients were higher than in healthy controls [18, 19]. IL-2 levels in patients aged 16-30 y were higher than in other age groups, and IL-2 levels in female patients were also higher than in males [18]. This is in line with the previous studies, that RAS usually began in the second decade of human life and was dominated by women in adult and pediatric patient groups [9]. Likewise, this is also in line with the study of RAS patients in India [26] and with burning mouth syndrome (BMS) patients in Croatia [28]. It implies that IL-2 is a biological marker that increases in active local oral mucosal inflammation, such as RAS and BMS.

IL-2 gene polymorphisms were also examined to determine the frequency of the IL-2 alleles and genotypes in RAS patients. Several 
significant differences in alleles, genotypes, and haplotypes were found between RAS patients and controls. The $\mathrm{G}$ to $\mathrm{T}$ exchange at position +166 of the IL-2 gene allows for increased IL-2 secretion [29]. These results align with other studies conducted in the Chinese population, in which IL-2 gene polymorphisms were associated with individual susceptibility to RAS [30]. The results of this review [22] and the two findings [29, 30], reinforce the recommendation that IL-2 can be used as a biomarker for diagnosis and determining risk factors for RAS.

IL-6 levels in the plasma of RAS patients showed a higher result than in healthy controls [20], and it aligns with the study in the atopic patient group with RAS [27]. IL-6 gene polymorphisms $(-174 G-C)$ and $(-572 G-C)$ were examined, and obtained results that these polymorphisms affect the formation and course of RAS [25]. Another study of IL-6 gene polymorphisms in the Iranian [31] and the DNA methylation of IL-6 in RAS patients with hematinic deficient and atopy in the Indonesian [32] population, also stated in a similar way, that IL- 6 played a role in the pathogenesis of RAS, but inconsistent with a study conducted in the Brazilian population, that found no difference in alleles and genotypes frequencies of the IL- 6 gene polymorphism $(-174 G-C)$ compared to controls [6]. Based on the data, IL-6 has good potential as a biomarker that plays a role in the pathogenesis of RAS in the proteomic level, however, the IL-6 gene polymorphisms and their relationship to RAS still require further investigation because there are still differences in the research results.

Examination of serum IL-8 levels was carried out to determine the effect of levamisole therapy in RAS patients. Serum IL-8 levels in RAS patients were significantly higher than in healthy controls before levamisole therapy, then IL-8 levels were reduced by $72 \%$ after levamisole therapy [21]. These results align with studies on other inflammatory diseases, which stated that IL-8 levels were higher in patients with Pyostomatitis vegetans [33]. So far, there have been no other studies examining IL-8 gene polymorphisms related to RAS.

Examination of IL-10 levels were found lower than in healthy controls [19], so this proves that IL-10 is an anti-inflammatory cytokine in RAS patients. The frequency of IL-10 alleles and genotypes had also been examined. It showed that the SNP of the IL10 gene was associated with an individual's predisposition to RAS. IL-10 gene polymorphisms at positions $1082(C / A), 819(C / T)$, and $592(C / A)$ were investigated and significantly higher in RAS patients compared to controls [24]. The results of this study are different from the previous study, which stated that the IL-10 genotype at position $1082(G / A)$ of the RAS patient group was not higher than that of healthy controls [6]. These differences can be attributed to differences in population heterogeneity [32], so the IL-10 gene polymorphism in RAS patients still needs further research.

The levels of IL-12 in the blood of RAS patients were higher than in healthy controls [19]. However, the frequency of IL-12 (A-188 C) alleles and genotypes in RAS and control patients of Iranians ethnicity, showed no significant differences. The lack of association between IL-12 polymorphism and RAS may indicate that IL-12 genomically does not have a significant role in the pathogenesis of RAS, but at the proteomic level, it can still be considered as a biomarker in RAS. Another previous study examined the IL-12A and IL-12B alleles and genotypes, stating that gene polymorphisms of IL12 were associated with individual susceptibility to RAS [30]. Because there are still differences, IL-12 cannot be recommended as a biomarker for RAS.

IL-18 levels had been examined and stated to be related to the pathogenicity of RAS because it was detected to be higher in RAS patients than in controls [20]. It aligns with another study that measured the relationship between IL-18 and psoriasis as an inflammatory disease. The pro-inflammatory activity of IL-18 has been observed in various cells and in various diseases. The imbalance of IL-18 levels can cause inflammation and various diseases [34]. IL-8 can be said to have potential as a biomarker at the proteomic level in RAS as an inflammatory disease, but there has not been adequate research data at the genomic level.

Based on the results of this review, it can be seen that several interleukins play a role in the pathogenesis of RAS, both at the proteomic and genomic levels. The authors can recommend that IL2, IL-6, IL-8, IL-10, IL-12, IL-18 at the proteomic level and IL-2 at the genomic level can be used as biomarkers of RAS, because several other studies had shown similar results which is in line with the results of our study. At the genomic level, for now, we only recommend IL-2 as a biomarker of RAS predisposing factors because several studies results had supported it, whilst IL-6, IL-10, and IL-12 still require further investigation.

The limitation of this review is the possibility that there are articles that are in accordance with the research objectives but cannot be identified in the database used, or the full paper is not available. Meanwhile, this review article can become an important information as the basis for further research in the field of oral medicine, related to oral inflammatory diseases (including RAS), and also in the pharmaceutical field related to specific targets in the development of anti-inflammatory drugs.

\section{CONCLUSION}

Interleukins that are recommended as a pro-inflammatory biomarker are IL-2, IL-6, IL-8, IL-12, and IL-18, while as an antiinflammatory is IL-10, at the proteomic level. Only IL-2 can be recommended as a biomarker at the genomic level, as other interleukins still require more investigations.

\section{ACKNOWLEDGEMENT}

None

\section{FUNDING}

Nil

\section{AUTHORS CONTRIBUTIONS}

All authors have contributed equally.

\section{CONFLICT OF INTERESTS}

\section{Declared none}

\section{REFERENCES}

1. Brocker C, Thompson D, Matsumoto A, Nebert DW, Vasiliou V. Evolutionary divergence and functions of the human interleukin (IL) gene family. Hum Genomics. 2010;5(1):30-55. doi: 10.1186/1479-7364-5-1-30, PMID 21106488.

2. Commins SP, Borish L, Steinke JW. Immunologic messenger molecules: cytokines, interferons, and chemokines. J Allergy Clin Immunol. 2010;125(2);Suppl 2:S53-72. doi: 10.1016/j.jaci.2009.07.008, PMID 19932918.

3. Lieberman M. Marks' basic medical biochemistry: A clinical approach. Vol 4th; 2017.

4. Morange M. The central dogma of molecular biology. Resonance. 2009;14(3):236-47. doi: 10.1007/s12045-009-0024-6.

5. Benveniste EN. Cytokines. Encycl Neurol Sci. 2014;1:921-5.

6. Guimaraes AL, Correia-Silva Jde F, Sa AR, Victoria JM, Diniz MG, Costa Fde 0, Gomez RS. Investigation of functional gene polymorphisms IL-1 $\beta$, IL-6, IL-10 and TNF- $\alpha$ in individuals with recurrent aphthous stomatitis. Arch Oral Biol. 2007;52(3):26872. doi: 10.1016/j.archoralbio.2006.08.008, PMID 17052682.

7. Chavan M, Jain H, Diwan N, Khedkar S, Shete A, Durkar S. Recurrent aphthous stomatitis: a review. J Oral Pathol Med. 2012;41(8):577-83. doi: 10.1111/j.1600-0714.2012.01134.x, PMID 22413800.

8. Cui RZ, Bruce AJ, Rogers RS. Recurrent aphthous stomatitis. Clin Dermatol. 2016;34(4):475-81. doi: 10.1016/j.clindermatol.2016.02.020, PMID 27343962.

9. Scully C, Porter S. Oral mucosal disease: recurrent aphthous stomatitis. Br J Oral Maxillofac Surg. 2008;46(3):198-206. doi: 10.1016/j.bjoms.2007.07.201, PMID 17850936.

10. Beguerie JR, Sabas M. Recurrent aphthous stomatitis: An update on etiopathogenia and treatment. J Dermatol Nurs Assoc. 2015;7(1):8-12. doi: 10.1097/JDN.0000000000000099.

11. Ślebioda Z, Szponar E, Kowalska A. Etiopathogenesis of recurrent aphthous stomatitis and the role of immunologic aspects: literature review. Arch Immunol Ther Exp (Warsz). 2014;62(3):205-15. doi: 10.1007/s00005-013-0261-y, PMID 24217985 . 
12. Portin P, Wilkins A. The evolving definition of the term "Gene" genetics. 2017;205(4):1353-64. doi: 10.1534/ genetics.116.196956, PMID 28360126.

13. Eguia Del Valle A, Martinez Conde Llamosas R, Lopez Vicente J, Uribarri Etxebarria A, Aguirre Urizar JM. Salivary levels of tumour necrosis factor-alpha in patients with recurrent aphthous stomatitis. Med Oral Patol Oral Cir Bucal. 2011;16(1):e33-6. PMID 20711148.

14. Akintoye SO, Greenberg MS. Recurrent aphthous stomatitis. Dent Clin North Am. 2014;58(2):281-97. doi: 10.1016/j.cden.2013.12.002, PMID 24655523.

15. Wu D, Xin J, Liu J, Zhou P. The association between interleukin polymorphism and recurrent aphthous stomatitis: A metaanalysis. Arch Oral Biol. 2018;93(May):3-11. doi: 10.1016/j.archoralbio.2018.05.011, PMID 29800802.

16. Albanidou-Farmaki E, Markopoulos AK, Kalogerakou F, Antoniades DZ. Detection, enumeration and characterization of $T$ helper cells secreting type 1 and type 2 cytokines in patients with recurrent aphthous stomatitis. Tohoku J Exp Med. 2007;212(2):101-5. doi: 10.1620/tjem.212.101, PMID 17548954.

17. Onwuegbuzie AJ, Leech NL, Collins KMT. Qualitative analysis techniques for the review of the literature. Qual Rep. 2012;17(28):1-28.

18. Kalpana R, Thubashini M, Sundharam BS. Detection of salivary interleukin-2 in recurrent aphthous stomatitis. J Oral Maxillofac Pathol. 2014;18(3):361. doi: 10.4103/0973029X.151313, PMID 25948989.

19. Avci E, Akarslan ZZ, Erten H, Coskun Cevher S. Oxidative stress and cellular immunity in patients with recurrent aphthous ulcers. Braz J Med Biol Res. 2014;47(5):355-60. doi: 10.1590/1414-431x20143714, PMID 24760117.

20. Lu J, Zhang $\mathrm{N}, \mathrm{Wu} \mathrm{C}$. LncRNA CASC 2 is upregulated in aphthous stomatitis and predicts the recurrence. BMC Oral Health 2020;20(1):12. doi: 10.1186/s12903-019-0993-0, PMID 31937279

21. Gupta P, Ashok L, Naik SR. Assessment of serum interleukin-8 as a sensitive serological marker in monitoring the therapeutic effect of levamisole in recurrent aphthous ulcers: A randomized control study. Indian J Dent Res. 2014;25(3):2849. doi: 10.4103/0970-9290.138293, PMID 25098981.

22. Najafi S, Yousefi H, Mohammadzadeh M, Bidoki AZ, Farhadi E, Rezaei N. Interleukin-2, interferon-gamma gene polymorphisms in recurrent aphthous stomatitis. Prague Med Rep. 2017;118(2 3):81-6. doi: 10.14712/23362936.2017.7, PMID 28922104.

23. Firouze Moqadam I, Najafi S, Mohammadzadeh M, Zare Bidoki A, Yousefi H, Farhadi E, Tonekaboni A, Meighani G, Mohammadzadeh M, Amirzargar AA, Rezaei N. Lack of association between interleukin-12 gene polymorphisms and recurrent aphthous stomatitis. Avicenna J Med Biotechnol. 2016;8(4):200-1. PMID 27920889.
24. Najafi S, Firooze Moqadam IF, Mohammadzadeh M, Bidoki AZ, Yousefi H, Farhadi E, Tonekaboni A, Meighani G, Amirzargar AA, Rezaei N. Interleukin-10 gene polymorphisms in recurrent aphthous stomatitis. Immunol Investig. 2014;43(4):405-9. doi: 10.3109/08820139.2014.880119, PMID 24564196.

25. Karakus N, Yigit S, Rustemoglu A, Kalkan G, Bozkurt N. Effects of interleukin (IL)-6 gene polymorphisms on recurrent aphthous stomatitis. Arch Dermatol Res. 2014;306(2):173-80. doi: 10.1007/s00403-013-1406-x, PMID 23982631.

26. Altay DU, Korkmaz M, Ergun S, Korkmaz H, Noyan T. Salivary irisin: potential inflammatory biomarker in recurrent apthous stomatitis patients. Eur Rev Med Pharmacol Sci. 2021;25(5):2252-9. doi: 10.26355/eurrev_202103_25257, PMID 33755963.

27. Nur'aeny N, Sufiawati I, Suwarsa 0, Gurnida DA. Serum IL-6 levels of atopic patients with recurrent aphthous stomatitis (RAS). Padjadjaran J Dent. 2019;31(1):20-4. doi: 10.24198/pjd.vol31no1.21223.

28. Simcic D, Pezelj Ribaric S, Gržic R, Horvat J, Brumini G, Muhvic Urek M. Detection of salivary interleukin 2 and interleukin 6 . In: Patients with burning mouth syndrome. Mediators of Inflammations 2006;2006. PMID 054632.

29. Bhosale SS, Rajput BS, Takkar H, Bhagat SV, Vagger RM, Shaikh MIK. Establishment of role of IL-2, IL-10 and IL-12 in patients with recurrent aphthous stomatitis-a clinical study. J Contemp Dent Pract. 2018;19(10):1242-5. doi: 10.5005/jp-journals10024-2411, PMID 30498180.

30. Sun M, Fu SM, Dong GY, Wu D, Wang GX, Wu Y. Inflammatory factors gene polymorphism in recurrent oral ulceration. J Oral Pathol Med. 2013;42(7):528-34. doi: 10.1111/jop.12048, PMID 23406059.

31. Najafi S, Yousefi H, Mohammadzadeh M, Bidoki AZ, Firouze Moqadam IF, Farhadi E, Amirzargar AA, Rezaei N. Association study of interleukin-1 family and interleukin- 6 gene single nucleotide polymorphisms in recurrent aphthous stomatitis. Int J Immunogenet. 2015;42(6):428-31. doi: 10.1111/iji.12228, PMID 26385127.

32. Nur'aeny N, Gurnida DA, Suwarsa O, Sufiawati I. The impact of DNA methylation on IL6 mRNA levels in hematinic deficiency and atopy-associated recurrent aphthous stomatitis patients. Int J Dent. 2021;2021:5560695. doi: 10.1155/2021/5560695, PMID 33936205.

33. Ficarra G, Baroni G, Massi D. Pyostomatitis vegetans: cellular immune profile and expression of IL-6, IL-8 and TNF-alpha. Head Neck Pathol. 2010;4(1):1-9. doi: 10.1007/s12105-0090149-7, PMID 20237982.

34. Lee JH, Cho DH, Park HJ. IL-18 and cutaneous inflammatory diseases. Int J Mol Sci. 2015;16(12):29357-69. doi: 10.3390/ijms161226172, PMID 26690141. 